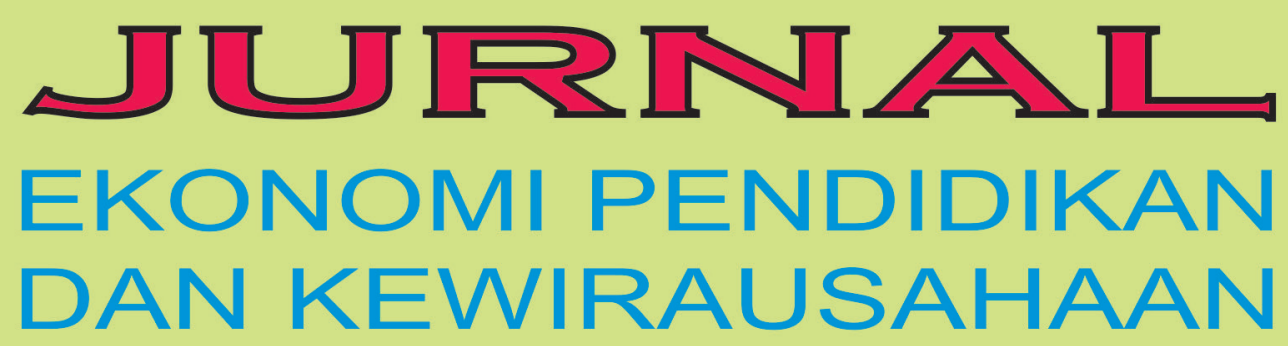

Pengaruh Hasil Belajar Pemasaran Online dan Hasil Belajar Kewirausahaan Terhadap Kinerja

Penjualan Online Peserta Didik SMK Negeri Surabaya

Hari Effendi

Pengaruh Motivasi Belajar, Sarana Belajar, Dan Percaya Diri Terhadap Hasil Belajar IPS Siswa

Penerima BSM (Bantuan Siswa Miskin) SMP Negeri di Surabaya

Studi Fenomenologi Financial Literacy Pengrajin Logam di Propinsi Jawa Timur

Murtiningsih

Lilia Pasca Riani

Pengaruh Latar Belakang Etnis, Kecerdasan Adversitas dan Regulasi Diri Dalam Belajar Terhadap Orientasi Wirausaha Siswa SMP Negeri 31 Surabaya

Setijo Wardayati

Pengaruh Latar Belakang Etnis, Kecerdasan Adversitas dan Regulasi Diri Dalam Belajar Terhadap

Orientasi Wirausaha Siswa SMP Negeri 31 Surabaya

Dwi Iga Luhsasi dan Arief Sadjiarto

Pengaruh Status Sosial Ekonomi Orangtua dan Hasil Belajar Ekonomi Terhadap Literasi Ekonomi di

SMP Negeri 43 Surabaya

Pengaruh Efektivitas Penggunaan Edmodo Terhadap Kepuasan Siswa di SMKN 1 Surabaya

Lilik Ernawati

Pengaruh Motivasi Belajar, Self Control dan Critical Thinking Terhadap Prestasi Belajar Mahasiswa

Prodi Pendidikan Ekonomi STKIP PGRI Situbondo

Heffrizza Ahmad

\author{
Jurnal Ekonomi Pendidikan dan Kewirausahaan \\ Program Studi Pendidikan Ekonomi Pascasarjana UNESA \\ Bekerjasama dengan \\ Asosiasi Profesi Pendidik Ekonomi Indonesia (ASPROPENDO)
}

Volume 5. Nomor 2. Oktober 2017

Halaman 159-276 


\section{JURNAL EKONOMI PENDIDIKAN DAN KEWIRAUSAHAAN}

Jurnal Ekonomi Pendidikan dan Kewirausahaan (JEPK) merupakan majalah ilmiah yang mempublikasikan artikel ilmiah hasil penelitian dalam bidang Pendidikan Ekonomi dan Kewirausahaan. JEPK diterbitkan secara berkala dua kali setahun, pada bulan April dan

Oktober.

\section{DEWAN REDAKSI}

\section{Ketua Editor}

Ady Soejoto, Universitas Negeri Surabaya

\section{Staf Editor}

Gimin, Universitas Riau

Waspodo Tjipto Subroto, Universitas Negeri Surabaya Muhammad Abdul Ghofur, Universitas Negeri Surabaya

Ni'matush Sholikhah, Universitas Negeri Surabaya

Bambang Ismanto, Universitas Kristen Satya Wacana

\section{Tim Review}

Neti Budiwati

Albrian Fiky Prakoso

Harti

Pujiati

Aniek Hindrayani
Universitas Pendidikan Indonesia

Universitas Negeri Surabaya

Universitas Negeri Surabaya

Universitas Lampung

Universitas Sebelas Maret

Sekretariat : Kampus Ketintang, Surabaya, 60231, Telepon/Faksimile +6231.8293484 Email: jepk@unesa.ac.id Web: https://journal.unesa.ac.id/index.php/jepk 